\title{
Teacher talking time: couldn't there be more?
}

\section{Ray Cooke}

\section{CpenEdition}

\section{Journals}

Electronic version

URL: http://journals.openedition.org/asp/2139

DOI: $10.4000 /$ asp. 2139

ISBN: 978-2-8218-0382-4

ISSN: 2108-6354

\section{Publisher}

Groupe d'étude et de recherche en anglais de spécialité

\section{Printed version}

Date of publication: 31 December 2000

Number of pages: $253-260$

ISSN: 1246-8185

\section{Electronic reference}

Ray Cooke, «Teacher talking time: couldn't there be more?», ASp [Online], 27-30 | 2000, Online since

28 January 2011, connection on 01 May 2019. URL : http://journals.openedition.org/asp/2139 ; DOI :

$10.4000 / a s p .2139$

This text was automatically generated on 1 May 2019.

Tous droits réservés 


\title{
Teacher talking time: couldn't there be more?
}

\author{
Ray Cooke
}

One of the more universally accepted tenets in EFL teaching in the past twenty years with the shift to learner-centred learning has been that it is preferable to reduce teacher talk (TT) so that learners may talk more. Indeed, there have been a considerable number of developments in that time to help teachers work in a more learner- and learning-centred way: detailed "press-the-button-and-go" teachers' manuals to accompany an everincreasing panoply of communicative methods declined in a multiplicity of levels and products including videos and CD-roms, photocopiable material for communicative activities at all levels of performance, etc. Yet it would be simplistic to see the question of TT only in quantitative terms whereby the quality of the teacher's intervention is largely judged by how much he can communicate or orchestrate in how few words. Moreover, this creates a dilemma: to what extent should the teacher feel obliged, in the name of any prevalent methodology, to toe the line and tone down his own TT when it might in fact be justified because of its content, quality, clarity or appropriateness in a given situation? After all, Krashen, one of the most influential thinkers of the eighties, argued for input to be comprehensible, of good quality and to be given in sufficient quantity. In addition, this issue is compounded by the context of ESP and its own sub-contexts. For example, in ESP, unlike in EFL, there is more at stake than teaching the communicative use of L2; there is also the content of the subject specialty per se. This article will make only passing reference to the evergreen question of what the ESP practitioner needs to know of the subject specialty he is working in. Rather it will attempt to demonstrate the specificity of the ESP context and discuss why, in the changing climate of ESP in France, there may be reasons in certain situations to increase TT.

What is the present situation of ESP in France? No simple overview can be made because of the multiplicity of situations in which ESP practitioners work. In the universities, a teacher may work with any group of students from those in the first year to postgraduates. Numbers also vary immensely, ranging from the quasi-crowds of the first year 
of study in disciplines such as the social sciences, as described by Pascal Fade (1993) to the discrete friendly ambiance of courses customized for the "Écoles Doctorales" and professionally-orientated programs such as the D.E.S.S. where a group of sixteen is widely considered as a maximum for efficient language teaching. A new trend for such students is the creation of courses aimed at individual skills such as technical writing or reading. The financial means available also have a bearing on numbers; money may be readily available for such high-flying students, whereas funding may be reduced for the heavily enrolled first- and second-year programs which consume many overtime teaching hours. These factors also have a bearing on the level of the learners. Clearly, a doctoral student will already possess vast subject-specific knowledge, while freshmen will probably need filling in regarding their own subject knowledge even when reading popularised articles. Finally, one must not forget the increasing importance of multimedia learning and the implications that this has and will have on the amount of time that the teacher may be required to spend in the actual presence of learners or in didactising material.

3 And this is considering only the universities. When one considers the increasing amount of ESP teaching officially required by the Ministry of Education in the professional lycées and other institutions, it is clear that there is a very wide spectrum of contexts in which ESP is practised, and an increasing number of colleagues being called upon to teach ESP, some of whom may feel at a loss both in pedagogical terms and regarding their own subject knowledge (e.g., the special English of car mechanics when you don't even know how to change a wheel!). On the other hand, the pool of experienced ESP practitioners is increasing year by year; teachers whose subject knowledge is now vast, who know how to update that knowledge and who are innovating by developing new modes of teaching to fit the means available to them. With so many different factors and situations, it is essential to proceed in a commonsense manner and to make sure that time spent is well spent and that the TT debate in ESP is presented both in qualitative and quantitative terms.

4 Since TT is authentic speech, then it is a component part of class input. We take it for granted now that learners need authentic input of various types if they are to learn to understand a second language well. Yet the choice of what will constitute that input is not an easy one, since it involves many of the factors mentioned above. For example, the use of a tape-recorded listening task might be inappropriate for a number of pedagogical, technical, and logistic reasons. Pedagogical, because the class level might be heterogeneous; technical, because the equipment may be inadequate or the acoustics poor; logistic, because of the size and shape of the room. In such circumstances, TT might be necessary to offset these inadequacies. Moreover, there is evidence that teachers intuitively modify their speech to accommodate their learners. Gaies (1977) taperecorded a group of native- and non-native-speaking trainee teachers in two contexts: a) with their peers, and b) in class with their students. In the classroom situation, they strongly adapted their speech. There was a constant trend to increase syntactic complexity with every incrementally increasing level of instruction, and the tendency was even greater when they addressed their peers. In fact, Gaies noted that the trainees intuitively placed their level of speech just above the level of comprehension of their learners, thus providing them on the spot with challenging input, and giving some substance to Krashen's well-known 'input + 1' notion whereby optimal input is of a level just above the learner's current level of interlanguage development. 
5 Since the eighties, neurolinguistic research has shown Krashen's input-acquisition paradigm to be an oversimplification of the language learning process. First, there is not one all-encompassing process but a plurality of processes involved in structuring language. Second, neither input nor acquisition would seem to be bounded domains but rather to be factors which feed off each other in a never-ending, upward movement. Yet we should not throw the baby out with the bath water. It is fast becoming standard practice today for almost the only help in comprehension to be provided by the very exercises and worksheets the learners are working on, while the teacher orchestrates the learning process from outside. While there can be no doubt about the necessity to didacticise authentic material upstream from a class session, it is probably sound practice for the teacher to intervene and stop collective class work temporarily if major comprehension problems occur so that the learners may be helped back onto the right track. Only TT can accomplish this. If this is done sensitively, there should be no need for the teacher to feel that he/she is hindering the flow of the class. And while TT does not fully reflect the richness of the language used by native speakers in the target-language world, it more than compensates in such situations since it is appropriate and clear at that precise moment. So TT should arguably be used to facilitate comprehension, provided the teacher has already done his/her "job" by destructuring the authentic document so that the learners are themselves stimulated to learn, and to learn how to learn.

6 Another current and future issue is whether this form of input (i.e., sound and image documents+worksheet) is in fact always in its right place (pedagogically and logistically speaking) in the classroom. The technical means and know-how are increasingly becoming available for learners to work efficiently alone or with each other in self-access centres and multimedia labs, thus freeing classroom time for other activities. The corollary is that the teacher is then able to speak in greater detail about the language, either to the whole class or on a one-to-one basis. In this setting, TT is not magisterial speech but the appropriate response to a precise need expressed at a given moment. In the ESP context, there are particular implications: more time becomes available for learning to read and write better by becoming aware of the particular grammatical and structural problems that speakers of French encounter in specialized English. As mentioned above, the needs of ESP learners vary considerably according to their level and career stage, so judicious choices must be made regarding what can and cannot be included in a training program. The spectrum ranges from the need to understand popularised scientific reports in the freshman year to grasping the schemata of technical writing or how weak or strong hedging may be in research reports. In any respect, with the increasing number of settings for language learning and the increasingly diversified and better understood needs of ESP learners, TT has its place very firmly, and temporarily, in the centre of a learning-centred approach.

7 Another complementary factor to consider is the accruing collective experience of ESP practitioners in France which is well supported by an extensive literature devoted largely to the French context, ${ }^{1}$ and by solid professional training. ${ }^{2}$ In fact, these practitioners quite simply now have many insights into the vast range of issues that ESP involves, and as such truly have something to say. Now this may sound specious, but it is through the cross-fertilization of knowledge in linguistic, didactic, cultural and technological factors ${ }^{3}$ that many of today's ESP practitioners in France are becoming aware not only of the complexity and richness of ESP, but also of how to see the wood among the trees. Whole 
new areas are emerging, such as FASP or "fiction à substrat professionnel" developed by Michel Petit (1999), in which segments of fictional works are studied for their professional ESP content. The approach opens up new research perspectives, both in linguistic terms and in didactic terms, since fiction has until now remained largely unexploited as source material in ESP. So it is not sufficient to stick to one's own corner of the woods in any one of these interlocking areas, because this will deprive learners of valuable insights into the workings of special Englishes, and many ESP teachers in France are called upon to intervene in a range of subject areas. This does not mean that a teacher's knowledge of the linguistic, didactic, cultural and technological facets of ESP should be the same - it could not be - but that he or she should at least have sufficient awareness of them to respond to learners' requirements as they arise. And when such knowledge is on hand, good quality TT is warranted.

Moreover, an emerging tendency is for the subject knowledge and language awareness of both ESP teacher and learner to be moving towards each other, at least in certain disciplines. For example, by the time doctoral students in biology have completed their first year of doctoral study, they will by and large be intuitively aware of certain processes involved in drafting an introduction to a research article, without ever having heard of discourse models such as the CARS model by Swales (1990). Indeed, they will possibly have already published in English as principal author. ${ }^{4}$ In other words, their language awareness will already be heightened by necessity. By the same token, the ESP practitioner's subject awareness is progressively heightened by working with such learners and their discourse. This tendency is well described by Monique Mémet (1999) when she discusses the necessary involvement of the ESP teacher in making doctoral students aware of the ethical issues implicit in writing up research. Such issues are no doubt discussed more nowadays in the ESP classroom in France than they were a dozen years ago. And this sort of teacher intervention may be required not only with doctoral students. For example, in a recent lesson with a group of masters biochemistry students, one of the learners could not understand the word "mitogen", even in context and after searching for meaning from the word group and the form of the word itself. Although I was unable to resist the temptation to tell her exactly what a mitogen is and how it functions, this situation demonstrates that the gap - gulf, some would fearfully say between our learners' subject knowledge and our own is generally closing. Therefore, as ESP practitioners, we may have more to contribute, and thus to say, than initially meets the eye.

9 This symbiosis between subject knowledge and language awareness is all the more striking in certain colleagues working exclusively in one subject area, as testified by recent contributions to the GERAS sub-group working sessions. ${ }^{5}$ Nowadays, it is not unusual for teachers of ESP appointed to faculties of medicine and pharmacy to be so fully integrated in their working environments that they are able to team-teach alongside teachers of the subject specialty. For example, in the mode which has come to be known as "enseignement intégré", ${ }^{6}$ the subject specialist agrees to lecture in English while the role of moderator or session manager is played by the language teacher. All interaction between lecturer and learners also takes place in English. There then follows a phase of reiteration headed by the language teacher in which not only errors of differing degrees of severity are corrected, either by the language teacher or sometimes by the participants, but also improvements in overall communicativeness are suggested. Therefore, the language teacher in this setting must assume a role which reaches well 
beyond his traditional mandate. He can do so only if he is conceptually well versed in medicine, for example, and also if he is acquainted with the do's and don'ts of speaking in public. Moreover, this sort of assistance is now being given on an individual basis in some universities. It may even be that in this setting, the language teacher does not speak quantitatively more but rather speaks of factors until now considered outside of his scope. In any respect, TT here is probably of better quality in this situation, provided that the teacher's intervention is timed correctly, is appropriate, and if each word is made to count.

10 This sort of trans-disciplinary involvement has another knock-on effect. An increasing number of ESP practitioners are now at home in their learners' science laboratories. More exactly, while clearly being unable to perform an experiment or even recognise equipment, they are able to use the laboratory as source material to obtain authentic documents, manuals, photos, graphs, etc., which may then be didacticised for class work. Indeed, there is an increasing trend for the laboratory and associated premises to become a complementary site for ESP teaching. For example, the University of Limoges has allocated funding from pharmaceutical companies for the construction and upkeep of a fully-equipped mock dispensary on the university premises. Students perform role plays, documentation searches and other activities under the guidance of the language teachers. So much conceptual knowledge rubs off in this way that the language teacher can speak more authoritatively about the specialty itself and its discourse features. In this respect, the symbiosis between subject knowledge and language awareness can only increase, thus giving the language teacher far more impact to his speech.

There are a number of settings in which the ESP practitioner will in future find that he/ she needs to talk more, but special mention should be made of the exponentially increasing need for technical reading and writing workshops. On the one hand, students who are unable to read technical English well and sign up to follow a reading course require a specific sort of assistance ${ }^{7}$ that may involve speaking both in the second and first language. The same is true for those in writing classes but on another level. The common factor between the two settings is the need to arouse language awareness. This is of course aroused by the didactisation of the authentic material itself, but more explanation is frequently required. Once again, providing the timing is right and verbosity is avoided, the teacher may find that he/she is talking, and saying, more.

12 A final way in which this expertise may be gained is through helping colleagues from other subject areas with proof-reading of research articles. More and more colleagues are now finding that they are being asked to provide this sort of help to others. In this way, the ESP practitioner acquires a vast knowledge base. Moreover, it progressively becomes clear how a lexical domain in one specialty will overlap another...but one finds this out only by contact with the terrain. In any respect, there is probably a crude yet constant relationship between what one knows of a subject specialty and what one can say about it.

13 The title of this paper is of course tendentious, and the remarks it contains should in no way be considered a plea for more magisterial speech in the ESP classroom. Moreover, the theme of when, why and how to correct, which would constitute another discussion entirely, has been purposely left aside. Rather, an argument has been made for more rationality in the way the teacher takes the floor. A delicate balance is to be struck: on the one hand, moving into the group of learners to give clear and concise instructions or to impart information about the language that the learners may have requested or have 
been diagnosed by the teacher as needing; and on the other, feeling when it is better to move out of the group so that learning may take place on an individual or peer basis. TT must always serve a purpose, a principle which all teachers sometimes forget. In conclusion, therefore, the issue of whether there could be more TT as ESP comes of age in France is one which is as much a qualitative one as it is a quantitative one, i.e., more TT if it is better and more appropriate TT.

\section{BIBLIOGRAPHY}

Allwright, Dick and Kathleen Bailey. 1991. Focus on the Language Classroom. Cambridge: Cambridge University Press.

Bowen, Tim and Jonathan Marks. 1994. Inside Teaching: Options for English language teachers. London: Heinemann.

Colle, Pierre-Emmanuel. 1998. "Recherche-action et problématique de la préparation à la communication médicale". ASp, 19-22, 389-396.

Cooke, Ray. 1995. "High level discourse and low level learners: An unlikely marriage”. ASp 7-10, 217-230.

Cullen, Richard. 1998. “Teacher talk and the classroom context”. ELT Journal 52/3, 179-187.

Fade, Pascale. 1993 “L'anglais de spécialité pour non-spécialistes niveau DEUG”. ASp 1, 287-300.

Gaies, S. J. 1977. "The nature of linguistic input in formal second language learning: Linguistic and communication strategies in ESL teachers' classroom language". In Brown H.D., C.A. Yorio and R.H. Crymes (eds.), On TESOL '77, Teaching and Learning English as a Second Language: Trends in research and practice. Alexandria, VA:TESOL, 204-212.

Jones, Jeremy. 1999. “From silence to talk: Cross-cultural ideas on students' participation in academic group discussion". English for Specific Purposes 18/3, 243-259.

Kramsch, Claire. 1993. Context and Culture in Language Teaching. Oxford: Oxford University Press.

Lynch, A. J. 1988. “Speaking up or talking down: foreign learners' reactions to teacher talk”. ELT Journal 42/2, 109-116.

Mémet, Monique. 1999. "Professional ethics and novice researchers". ASp 23-26, 509-517.

Nunan David and Clarence Lamb. 1996. The Self-directed Teacher: Managing the learning process. Cambridge: Cambridge University Press.

Petit, Michel. 1999. "La fiction à substrat professionnel : une autre voie d'accès à l'anglais de spécialité”. ASp 23-26, 57-81.

Van Lier, Leo. 1996. Interaction in the Language Curriculum. Harlow: Addison Wesley Longman, 128-133. 


\section{NOTES}

1. For example, ASp and Cahiers de l'APLIUT.

2. The "D.E.A. de langue anglaise des spécialités scientifiques et techniques" jointly organized by the Universities of Bordeaux 2, Montpellier 3, Paris 4, Toulouse 1 and ENS Cachan represents a solid platform for the training of practising and future ESP teachers.

3. i.e., the areas covered by the "D.E.A. de langue anglaise des spécialités scientifiques et techniques".

4. To stand any chance of becoming maitre de conférences in biology, a candidate needs a minimum of about six publications in English. Indeed, very few French biologists publish new experimental results in French nowadays.

5. The GERAS (Groupe d'étude et de recherche en anglais de spécialité) has in recent years organized pedagogical working sessions according to theme areas, e.g., economics, health-related disciplines, etc. Those involved in teaching the English of such subjects discuss many aspects concerning pedagogy, organisational strengths and weaknesses, learning strategies, etc., and how these parameters interact.

6. See Colle (1998).

7. See Cooke (1995).

\section{ABSTRACTS}

Since the end of the 1970s, there has been much emphasis in language teaching and learning on minimising teacher intervention in class and optimising classroom time for group learning. Indeed, it is now a widely held belief that diminishing teacher talking (TT) time is desirable, since time spent listening to the teacher is time lost for communication between learners and for personal work. There can be no doubt regarding the sound pedagogic foundations of this standpoint. However, as ESP and its practitioners come of age in France, the author argues that there is some scope for mitigation of this position, and that the TT debate is not only a quantitative but also qualitative one. In summary, a set of apparently disparate but complementary conditions are opening the way for ESP practitioners in France to feel more confident about increasing their TT in certain circumstances.

Depuis la fin des années 1970, il est fortement question dans l'enseignement et l'apprentissage des langues vivantes de minimiser le temps de parole de l'enseignant pour optimiser le temps d'apprentissage en groupe. En effet, le temps passé à écouter l'enseignant serait autant de temps perdu pour la communication entre apprenants et pour le travail personnel. Les fondements pédagogiques d'une telle opinion paraissent dorénavant acquis. En revanche, la maturité grandissante de l'anglais de spécialité en France, et de ses praticiens, permettrait d'atténuer cette position. L'auteur plaide donc en faveur d'aspects aussi qualitatifs que quantitatifs de cette problématique. Il émet l'hypothèse qu'il existe déjà un ensemble de conditions apparemment disparates mais complémentaires qui amènerait les praticiens de l'anglais de spécialité en France à se sentir plus à l'aise pour augmenter leurs temps de parole en certaines circonstances. 
INDEX

Mots-clés: anglais de spécialité, besoins, contenu, didactisation, enseignant, temps de parole

Keywords: didactisation, ESP, learners' need, talking time, teacher talk

AUTHOR

RAY COOKE 